\title{
HUBUNGAN MEKANISME KOPING DENGAN TINGKAT ANSIETAS PADA KLIEN DENGAN PENYAKIT KANKER DI RSPAD GATOT SOEBROTO
}

\author{
Zakiyah Mujahidah $^{(1)}$, Suwarningsih Soeharto ${ }^{(2)}$, Tika Silviasari $^{(3)}$ \\ Program studi S1 Keperawatan Universitas MH. Thamrin \\ zakiyahmujahidah@gmail.com
}

\begin{abstract}
Cancer is a disease caused by abnormal growth of cells of the body tissues will be change the cancer cells. Patients who get cancer will get anxiety or commonly called 'kecemasan'. Anxiety is a feeling of unidentified fear and is not supported by the situation. Anxiety can be handle with coping mechanisms. Coping mechanism have two type, they are namely adaptive coping mechanism and maladaptive coping mechanism. This research using descriptive method with cross sectional approach and chi square test to find corellation between coping mechanism and anxiety level on clients with cancer at RSPAD Gatot Soebroto with 66 respondents. The results of research was held on August 2017 there were (51.5\%) patients with maladaptive coping mechanisms and (48.5\%) patients with adaptive coping mechanisms. Patients with low anxiety were $(16.7 \%)$, middle anxiety $(62.1 \%)$ and heavy anxiety $(21.2 \%)$ with p-values 0.735 and $0.537, \alpha=0.05$ OR $=0.652$ (95\% CI 0.171-2.485) and OR = 1.704 (95\% CI 0.500-5.800). The conclusion of this research, it is not found the significant correlation between coping mechanisms and anxiety level on clients with cancer at RSPAD Gatot Soebroto . Based on the result of this research showing that is good coping mechanism can be reduce anxiety level on cancer patients.
\end{abstract}

Keywords : Cancer, Anxiety, Coping Mechanism

\section{PENDAHULUAN}

Penyakit terminal menurut Kemenkes (2007) dikategorikan dalam beberapa jenis meliputi kanker, penyakit degeneratif, paru obstruktif kronis, cystic fibrosis, stroke, parkinson, gagal jantung, kelainan genetika dan penyakit infeksi seperti HIV/AIDS. Data WHO menunjukkan kanker merupakan penyebab kematian tertinggi ketiga yaitu 8,2 juta penderita pada tahun 2013 dan meningkat menjadi 8,8 juta kematian pada tahun 2015. Data GLOBOCAN (IARC) secara nasional penyakit kanker pada penduduk semua umur di Indonesia tahun 2013 diperkirakan sekitar 347.792 orang. DKI Jakarta merupakan provinsi ketiga tertinggi angka kejadian kanker sebanyak 19.004 orang, terbagi menjadi 2 jenis kanker terbanyak yaitu kanker serviks 5.919 orang dan kanker payudara 3.946 orang. Namun data tersebut berbeda dengan data dari RSPAD Gatot Soebroto menjelaskan bahwa angka kejadian kanker yang terjadi di RSPAD Gatot Soebroto dalam 2 bulan terakhir yaitu 528 kasus kanker dengan angka tertinggi yaitu kanker payudara (Ca mamae), kanker ovarium dan kanker nasofaring. WHO (2010) memaparkan dampak dari penyakit kanker tidak hanya menyerang fisik. Akan tetapi kanker dapat menyerang psikologis, sosial dan spiritual seseorang. Kondisi psikologis dari mulai mengalami kecemasan ringan, ketakutan sampai dengan depresi karena tidak mudah menjalani hidup sebagai penderita kanker. Salah satu dampak psikologis pada penderita kanker mengalami kecemasan atau ansietas. Insiden kejadian ansietas pada penderita kanker sebanyak 50\% pada penelitian Haris (2015) pada pasien kanker paru di RS Persahabatan Jakarta.

Kecemasan merupakan kekhawatiran yang tidak jelas dan menyebar yang berkaitan dengan perasaan tidak pasti, merupakan respon emosional dengan bermacam perasaan tidak menyenangkan yang ditimbulkan oleh hal yang tidak jelas, individu sering mengalami ketidakseimbangan yang membuatnya cemas, sedih, atau gelisah dan tidak bisa tidur yang dipicu oleh ketakutan (Stuart 2013). Perubahan fisiologis yang ditimbulkan dari kecemasan seperti: gemetar, berkeringat, detak jantung meningkat, nyeri abdomen, sesak nafas dan perubahan 
perilaku seperti: gelisah, bicara cepat, reaksi terkejut dan secara tidak langsung melalui timbul gejala sebagai upaya untuk melawan kecemasan. Takut merupakan penilaian intelektual terhadap ssuatu yang berbahaya, sedangkan ansietas adalah respon emosional terhadap penilaian tersebut (Keliat, 2012).

Penelitian Rahmawati, dkk (2015) menjelaskan adanya hubungan antara mekanisme koping pasien dengan tingkat kecemasan pada pasien kanker yang mendapat kemoterapi di Ruang Kemoterapi RS Urip Sumoharjo Bandar Lampung Tahun 2015 dengan jumlah responden sebanyak 90 orang. Penelitian tersebut tmelaporkan bahwa sebagian besar pasien menjalani kemoterapi di Ruang Kemoterapi RS Urip Sumoharjo Bandar Lampung memiliki tingkat kecemasan ringan yaitu 53 orang (58,9\%), kecemasan sedang 27 orang (30\%), kecemasan berat 3 orang $(3,3 \%)$ dan yang tidak cemas 7 orang $(7,8 \%)$.

Koping pasien dapat dijadikan pedoman untuk mengontrol emosi dan stress (Rasmun, 2004) dalam Manurung (2016). Koping dipandang sebagai suatu faktor penyeimbang yang dapat membantu individu beradaptasi dengan kondisi yang menekan. Koping adalah mekanisme untuk mengatasi perubahan yang dihadapi oleh individu. Mekanisme koping ini dapat berhasil apabila seseorang dapat beradaptasi terhadap perubahan tetapi koping tidak dapat berhasil akan berdampak pada gangguan kejiwaan. Setiap individu, dalam menghadapi masalah yang sama akan berbeda-beda dalam menggunakan kopingnya (Safaria \& Saputra, 2009).

Hasil studi pendahuluan yang dilakukan melalui metode wawancara pada 27 pasien yang menderita penyakit kanker yaitu penyakit ini sangat berpengaruh terhadap aktivitas pasien mulai dari terbatasnya ruang gerak klien, menurunnya kinerja organ-organ gerak yang dapat menghambat aktivitas harian klien. Terdeteksinya kanker secara dini juga sangat berpengaruh terhadap kemampuan dalam menangani penyakit kanker sehingga klien dapat dengan cepat mendapatkan tindakan untuk pencegahan terjadinya pertumbuhan sel-sel kanker yang abnormal. Klien akan melakukan segala upaya untuk pencegahan diantaranya dengan cara mencari informasi pengobatan alami atau herbal terkait penyakitnya maupun dengan melakukan medical check up rutin ke RS. Kecemasan selalu timbul pada penderita kanker, namun penderita mengatasinya dengan cara lebih menyibukkan diri atau mendekatkan diri kepada yang maha kuasa. Dari data studi pendahuluan terdapat 33\% pasien yang mengalami kecemasan ringan dan $12 \%$ pasien mengalami kecemasan sedang. Pasien kanker tersebut menggunakan mekanisme koping, 77\% pasien menggunakan mekanisme koping adaptif dan 23\% pasien menggunakan mekanisme koping maladptif. Pemahaman pasien yang baik tentang penyakit kanker akan mengurangi kecemasan dan meningkatkan kepatuhan pada pasien yang baru terdiagnosis kanker terhadap pengelolaan penyakitnya. Data diatas menunjukkan bahwa kejadian penyakit kanker cukup tinggi maka penulis tertarik untuk melakukan penelitian lebih lanjut guna mengetahui seberapa jauh hubungan mekanisme koping dengan tingkat ansietas pada klien dengan penyakit kanker.

\section{METODE}

Rancangan penelitian pada penelitian ini menggunakan jenis penelitian kuantitatif dengan mengkaji hubungan atau variabel. Tujuan dari penenlitian ini untuk mengetahui apakah ada hubungan mekanisme koping dengan tingkat ansietas pada klien dengan penyakit kanker di ruang kemoterapi RSPAD Gatot Soebroto Jakarta Pusat, maka berdasarkan tujuan penelitian tersebut desain penelitian yang digunakan adalah rancangan penelitian cross sectional (Nursalam, 2016). Responden pada penelitian ini ialah seluruh klien dengan penyakit kanker 
yang menjalani kemoterapi di RSPAD Gatot Soebroto Jakarta Pusat. Teknik pengambilan sampel ini adalah purposive sampling. Suatu teknik penetapan sampel dengan cara memilih sampel di antara populasi sesuai dengan yang dikehendaki peneliti (tujuan/masalah dalam penelitian) disebut purposive sampling, sehingga sampel tersebut dapat mewakili karakteristik populasi yang telah dikenal sebelumnya. Pada penelitian ini jumlah minimal sampel yang diperlukan adalah 59 orang klien dengan penyakit kanker

\section{ANALISA DATA}

\section{Analisis Univariat}

Notoatmodjo (2010) menjelaskan analisis univariat diperlukan untuk mendeskripsikan karakteristik setiap variabel penelitian. Analisis univariat dilakukan untuk mengetahui distribusi frekuensi dari variabel dependen yaitu tingkat ansietas pada klien dengan penyakit kanker. Adapun variable yang dilakukan analisa univariat meliputi: usia, jenis kelamin, pendidikan, jenis kanker, pengalaman kemoterapi, tingkat ansietas, mekanisme koping.

\section{Analisa Bivariat}

Analisis bivariat diperlukan untuk menjelaskan dua variabel yang berbeda, yang diduga berhubungan atau berkorelasi (Notoatmodjo, 2010). Pada penelitian ini analisis bivariat digunakan untuk mengetahui apakah ada hubungan mekanisme koping dengan tingkat ansietas pada pasien dengan penyakit kanker dengan menggunakan uji sattistik chi-square.

Keputusan uji:

a. Bila nilai p-value $\leq$ nilai $\alpha 0,05$ maka Ho ditolak, data mendukung adanya perbedaan yang bermakna (signifikan)

b. Bila nilai p-value> nilai $\alpha 0,05$ maka Ho gagal ditolak, data tidak mendukung adanya perbedaan yang bermakna (signifikan) (hastono, 2007).

Pada analisis bivariat juga akan dinilai odds ratio (OR) yang merupakan nilai estimasi untuk menilai besarnya keeratan hubungan antara dua variabel yang diuji. Perubahan satu unit independen estimasi confidence interval (CI), OR ditetapkan pada tingkat kepercayaan 95\%. Berikut Interpretasi nilai Odds Ratio:

$\mathrm{OR}=1$ menunjukan besarnya resiko adalah sama,semakin besar nilai OR maka semakin pajanan suatu faktor resiko terjadi pada kelompok kasus dibandingkan dengan kelompok kontrol. Nilai OR kurang dari 1 menunjukan hal sebaliknya (Dharma, 2011).

\section{HASIL}

\section{Analisa Univariat}

\section{a. Usia}

Responden paling banyak pada rentang usia 40-49 tahun sebanyak 25 orang (37,9\%) dan tertinggi kedua pada usia 50-59 tahun terdapat 18 orang $(27,7 \%)$. 


\section{b. Jenis Kelamin}

Responden perempuan dua kali lebih banyak dibandingkan pasien laki-laki. Pasien dengan jenis kelamin perempuan sebanyak 45 orang $(68,2 \%)$ dan pasien dengan jenis kelamin laki-laki sebanyak 21 orang $(31,8 \%)$.

\section{c. Pendidikan}

Responden dominan berpendidikan terakhir SMA sebanyak 26 orang $(39,4 \%)$ dan tertinggi kedua yaitu S1 sebanyak 13 orang $(19,7 \%)$.

\section{d. Jenis Kanker}

Jenis kanker yang diderita responden terbanyak adalah ca mamae sebanyak 24 orang $(36,4 \%)$ dan ca nasofaring sebanyak 16 orang $(24,2 \%)$.

\section{e. Pengalaman Kemoterapi}

Pengalaman kemoterapi responden terbanyak berada pada tahap awal kemoterapi yaitu sebanyak 54 orang $(81,8 \%)$.

\section{f. Tingkat ansietas}

Responden kebanyakan mengalami ansietas sedang. Hal ini ditunjukkan dari hasil penelitian yaitu 41 orang $(62,1 \%)$ mengalami ansietas sedang, 14 orang $(21,2 \%)$ mengalami ansietas berat dan 11 orang $(16,7 \%)$ mengalami ansietas ringan.

\section{g. Mekanisme Koping}

Responden lebih banyak menggunakan mekanisme koping adaptif yaitu sebanyak 34 orang $(51,5 \%)$ dan responden yang menggunakan mekanisme koping maladaptif sebanyak 32 orang $(48,5 \%)$.

\section{Analisa Bivariat}

\section{a. Analisis Hubungan Antara Mekanisme Koping Dengan Tingkat Ansietas Pada Pasien Dengan Penyakit Kanker Di RSPAD Gatot Soebroto}

Sebagian besar pasien memiliki tingkat kecemasan sedang menggunakan mekanisme koping adaptif (75\%) sedangkan pasien dengan tingkat kecemasan ringan yang menggunakan mekanisme koping adaptif (25\%). Pasien dengan tingkat kecemasan sedang yang menggunakan mekanisme koping yang maladaptif $(82,1 \%)$ dan pasien dengan tingkat kecemasan ringan menggunakan mekanisme koping maladaptif (17,9\%). Berdasarkan hasil uji analisis diperoleh p-value 0,735 hasil ini lebih besar dari $\alpha$ (0.05) yang artinya Ho gagal ditolak, data tidak mendukung adanya perbedaan yang bermakna (signifikan) dan diperoleh OR 95\% CI untuk mekanisme koping sebesar 0,652dengan nilai lower 0,171 dan upper 2,485artinya pasien kanker dengan mekanisme koping maladaptif memiliki peluang 0,652 kali lebih besar mengalami ansietas sedang dibandingkan dengan pasien kanker yang menggunakan mekanisme koping adaptif.

b. Analisis Hubungan Antara Mekanisme Koping Dengan Tingkat Ansietas Pada Pasien Dengan Penyakit Kanker Di RSPAD Gatot Soebroto

Sebagian besar pasien memiliki tingkat kecemasan sedang menggunakan mekanisme koping adaptif $(69,2 \%)$ sedangkan pasien dengan tingkat kecemasan berat yang menggunakan mekanisme koping adaptif $(30,8 \%)$. Pasien dengan tingkat kecemasan sedang yang menggunakan mekanisme koping yang 
maladaptif $(79,3 \%)$ dan pasien dengan tingkat kecemasan berat menggunakan mekanisme koping maladaptif (20,7\%). Berdasarkan hasil uji analisis diperoleh p-value 0,537 hasil ini lebih besar dari $\alpha$ (0.05) yang artinya Ho gagal ditolak, data tidak mendukung adanya perbedaan yang bermakna (signifikan) dan diperoleh OR 95\% CI untuk mekanisme koping sebesar 1,704 dengan lower 0,500 dan upper 5,800artinya pasien kanker dengan mekanisme koping maladaptif memiliki peluang 1,704 kali lebih besar mengalami ansietas berat dibandingkan dengan pasien kanker yang menggunakan mekanisme koping adaptif.

\section{PEMBAHASAN}

\section{Usia Pada Pasien Dengan Penyakit Kanker}

Berdasarkan penelitian yang dilakukan didapatkan hasil bahwa pada pasien kanker yang menjalani kemoterapi paling banyak pada rentang usia 40-49 tahun sebanyak 25 orang $(37,9 \%)$ dan tertinggi kedua pada usia 50-59 tahun terdapat 18 orang $(27,7 \%)$. Usia responden pada penelitian ini sesuai dengan kriteria inklusi peneliti yaitu usia diatas 21 tahun. Peneliti memilih usia di atas 21 tahun karena pada penelitian ini peneliti ingin meneliti adanya hubungan antara mekanisme koping dengan tingkat ansietas pada responden dengan usia dewasa. Sholeh (2012) menyebutkan dengan bertambahnya usiapun dapat memicu terjadinya kanker. Usia diatas 30 mempunyai kemungkinan lebih besar terkena kanker dan kemungkinan bertambah setelah menopause pada wanita (ACS, 2009) dalam Subagja (2014). Pernyataan tersebut juga dibuktikan dalam penelitian Rianti (2012) bahwa 60,5\% penderita kanker berusia $\leq 50$ tahun. Selain itu, pada penelitian Sonia Gina, dkk (2014) juga memaparkan bahwa angka tertinggi pasien kanker berada pada usia 40-49 tahun $(37,3 \%)$.

\section{Jenis Kelamin pada Pasien dengan Penyakit Kanker}

Berdasarkan penelitian yang dilakukan didapatkan hasil bahwa pasien perempuan dua kali lebih banyak dibandingkan pasien laki-laki. Pasien dengan jenis kelamin perempuan sebanyak 45 orang $(68,2 \%)$ dan pasien dengan jenis kelamin laki-laki sebanyak 21 orang $(31,8 \%)$. Hal ini disebabkan oleh lebih banyaknya ruangan untuk pasien perempuan dibandingkan untuk pasien laki-laki dan lebih sedikitnya pasien kanker berjenis kelamin laki-laki melakukan kemoterapi. Hasil penelitian tersebut sesuai dengan teori (Sholeh, 2012) yaitu kanker payudara lebih banyak ditemukan pada wanita walaupun terdapat juga kasus kanker pada pria.

\section{Pendidikan Terakhir pada Pasien dengan Penyakit Kanker}

Berdasarkan penelitian yang dilakukan didapatkan hasil bahwa pasien kanker yang menjalani kemoterapi dominan berpendidikan terakhir SMA sebanyak 26 orang $(39,4 \%)$ dan tertinggi kedua yaitu S1 sebanyak 13 orang (19,7\%). Hasil penelitian ini didukung oleh teori Notoatmojo (2010) dimana pengetahuan atau kognitif merupakan domain yang penting untuk terbentuknya tindakan, perilaku yang didasari dengan pengetahuan akan lebih langgeng daripada yang tidak didasari pengetahuan.

\section{Jenis Kanker yang dilakukan Kemoterapi}

Berdasarkan penelitian yang dilakukan pada pasien kanker yang menjalani kemoterapi terbanyak didiagnosa ca mamae sebanyak 24 orang $(36,4 \%)$ dan ca nasofaring sebanyak 16 orang $(24,2 \%)$. Hal ini sesuai dengan 
data dari RSPAD Gatot Soebroto bahwa angka kejadian kanker yang tertinggi yaitu kanker payudara (mamae) dan kanker nasofaring (KNF).

\section{Jumlah Kemoterapi pada Pasien dengan Penyakit Kanker}

Berdasarkan penelitian yang dilakukan didapatkan hasil terbanyak pada pasien kemoterapi tahap awal yaitu sebanyak 54 orang $(81,8 \%)$. Pengobatan kemoterapi dilakukan setelah pasien terdiagnosa kanker. Pada saat penelitian, peneliti lebih banyak mengambil sampel dari responden yang menjalani kemoterapi tahap awal karena pada saat tahapan awal, pasien akan memberikan respon yang berbeda dengan pasien yang sudah melakukan kemoterapi tahap lanjutan.

\section{Mekanisme Koping pada Pasien dengan Penyakit Kanker}

Hasil penelitian menunjukkan lebih dari separuh responden menggunakan mekanisme koping adaptif $(48,5 \%)$ dan sisanya $(51,5 \%)$ menggunakan mekanisme koping maladaptif. Hal ini sesuai dengan penelitian yang dilakukan oleh Mualim, dkk (2015) yang menyatakan bahwa 52,8\% pasien kanker menggunakan mekanisme koping maladaptif dan 47,2\% pasien menggunakan mekanisme koping adaptif. Hal ini disebabkan oleh masalah psikologis yang dirasakan oleh klien seperti rasa trauma atau mengingat kematian. Berbeda dengan penelitian diatas, penelitian Sonia Gina, dkk (2014) memaparkan bahwa lebih banyak pasien menggunakan mekanisme koping adaptif dibandingkan mekanisme koping maladaptif. Dari jumlah responden sebanyak 59 orang terdapat $61 \%$ pasien kanker menggunakan mekanisme koping adaptif dan 39\% pasien kanker menggunakan mekanisme koping maladaptif. Hal ini dipicu oleh sedikitnya angka kejadian ansietas/depresi yang dialami oleh pasien kanker sehingga lebih banyak pasien menggunakan mekanisme koping adaptif. Siswanto (2007) menjelaskan mekanisme koping adalah sebagai apa yang dilakukan oleh individu untuk menguasai situasi yang dinilai sebagai suatu tantangan, luka, kehilangan, atau ancaman. Koping strategi seharusnya dapat dikendalikan secara personal, akan tetapi lingkungan sosial dapat pula mempengaruhi koping secara individu (Carver \& Connor-Smith, 2010). Pada penelitian ini, pasien menilai penyakit kanker merupakan suatu tantangan atau ancaman sehingga pasien tidak dapat mengendalikan situasi dengan baik sehingga lebih banyak menggunakan mekanisme koping maladaptif dibandingkan dengan pasien yang menggunakan mekanisme koping adaptif. Sedangkan pada penelitian lain, responden menilai penyakit kanker merupakan suatu ancaman yang masih wajar sehingga responden masih mampu mengatasi penyakit yang dideritanya. Hal tersebut dapat dilihat dari hasil penelitian yaitu lebih dari separuh pasien menggunakan mekanisme koping adaptif sehingga pasien dapat mengatasi penyakitnya dengan cara yang lebih baik dibandingkan dengan pasien yang menggunakan mekanisme koping maladaptif.

\section{Tingkat Ansietas pada Pasien dengan Penyakit Kanker}

Hasil penelitian menunjukkan bahwa sebagian besar responden mengalami ansietas sedang $(62,1 \%)$, sedangkan pasien yang mengalami ansietas berat $(21,2 \%)$ dan pasien yang mengalami ansietas ringan (16,7\%). Sesuai dengan penelitian Susilawati, Dwi (2013) yang memaparkan bahwa mayoritas responden mangalami ansietas sedang (50\%). Susilawati (2013) menjalaskan bahwa orang tua/dewasa apabila dihadapkan dengan penyakit yang menggancam akan menimbilkan pengalaman-pengalaman kecemasan. Selain itu, penderita penyakit kanker ini dikuasai perasaan tidak berguna, malu, serta khawatir akan menjadi 
beban orang lain sehingga menyebabkan kecemasan. Penelitian yang dilakukan oleh Susilawati (2013) sesuai dengan hasil penelitian yang dilakukan oleh peneliti di RSPAD Gatot Soebroto, Jakarta Pusat.

Penelitian yang dilakukan oleh Nurpeni, dkk (2014) menyebutkan bahwa sebagian besar $(31,7 \%)$ pasien kanker mengalami kecemasan berat. Sebagian besar pasien mengalami kecemasan berat dapat disebabkan oleh terjadinya penurunan fungsi fisik, kehilangan pekerjaan, efek dari kemoterapi, biaya rumah sakit yang cukup tinggi, keadaan keluarga setelah pasien masuk rumah sakit dan takut akan kematian. Hal tersebut berbeda dengan hasil penelitian yang dilakukan oleh peneliti.

Ansietas adalah suatu perasaan takut yang tidak menyenangkan dan tidak dapat dibenarkan yang sering disertai gejala fisiologis, sedangkan pada gangguan ansietas terkandung unsur penderitaan yang bermakna dan gangguan fungsi yang disebabkan oleh kecemasan tersebut (Riyadi \& Purwanto, 2010).

Pada penelitian ini, gejala fisiologis yang ditimbulkan tidak menimbulkan penderitaan yang bermakna bagi pasien kanker yang menjalani kemoterapi. Hal ini disebabkan oleh pasien yang terkena penyakit kanker lebih berfokus kepada pekerjaan lain yang dapat membuat pasien mengalihkan rasa cemasnya. Terjadi kesenjangan antara penelitian ini dengan penelitian yang dilakukan oleh Nurpeni, dkk (2014). Pada penelitian Nurpeni, dkk (2014) pasien kanker mengalami kecemasan berat dikarenakan ketakutan yang berlebihan akan adanya perubahan fisik, psikologis serta takut akan terjadinya kematian.

\section{Hubungan Mekanisme Koping dengan Tingkat Ansietas pada Pasien dengan Penyakit Kanker}

Dari hasil Uji Chi Square antara mekanisme koping dengan tingkat ansietas ringan dan sedang dijelaskan bahwa dengan tingkat signifikan $(\alpha=0,05)$ didapatkan hasil nilai $\mathrm{p}>\alpha$ yaitu $0,735>0,05$ sedangkan pada hasil uji Chi Square antara mekanisme koping dengan ansietas sedang dan ansietas berat dijelaskan bahwa dengan tingkat signifikan $(\alpha=0,05)$ didapatkan hasil nilai $p>\alpha$ yaitu $0,537>0,05$ sehingga Ho gagal ditolak yang artinya data sampel tidak mendukung adanya perbedaan yang bermakna (signifikan) antara mekanisme koping dengan meningkatnya kejadian ansietas pada pasien dengan penyakit kanker di RSPAD Gatot Soebroto.

Penelitian dilakukan Rahmawati (2015) terdapat lebih dari separuh responden menggunakan mekanisme koping yang adaptif mengalami cemas ringan sampai sedang. Hasil penelitian Rahmawati (2015) menunjukkan dari 31 responden yang mempunyai mekanisme koping maladaptive sebanyak 16 (51,6\%) mengalami cemas sedang, sedangkan dari 59 responden yang memiliki koping mekanisme adaptif sebanyak 41 orang $(69,5 \%)$ mengalami cemas ringan. Dari hasil uji statistic diperoleh p value sebesar 0,004 (lebih kecil dri alpha) yang berarti yang berarti Ho ditolak, sehingga dapat disimpulkan bahwa ada hubungan yang bermakna antara mekanisme koping dengan tingkat kecemasan pada pasien kanker yang mendapat kemoterapi di ruang Kemoterapi RS Urip Sumoharjo Bandar Lampung tahun 2015.

Stuart (2007) dalam Rahmawati (2015) menjelaskan sumber koping yang dimanfaatkan dengan baik seperti keberadaan dukungan keluarga dapat membantu pasien mengembangkan mekanisme koping yang adaptif, sehingga pasien dapat menanggulangi kecemasannya ditandai dengan tingkat kecemasan yang ringan dan sedang. Hal ini sesuai dengan teori (Rochman, 2010) yaitu perasaan yang tidak menentu pada umumnya tidak menyenangkan yang nantinya akan menimbulkan atau disertai perubahan fisiologis dan psikologis. 
Berdasarkan penelitian diatas maka terdapat kesenjangan antara penelitian ini dengan penelitian yang dilakukan oleh Rahmawati (2015). Hal ini dikarenakan respon cemas seseorang tergantung pada kematangan pribadi, pemahaman dalam menghadapi tantangan, harga diri dan mekanisme koping yang digunakan. Sehingga pada pasien kanker yang mejalani kemoterapi akan berespon berbeda-beda sesuai dengan adanya perubahan fisiologis maupun psikologis.

\section{KESIMPULAN DAN REKOMENDASI}

Tidak ada hubungan bermakna antara mekanisme koping dengan tingkat ansietas pada klien dengan penyakit kanker di RSPAD Gatot Soebroto; Responden pada penelitian berdasarkan usia tertinggi yaitu pada rentang usia 40-49 tahun sebanyak 25 orang (37,9\%), jenis kelamin mayoritas adalah perempuan 45 orang $(68,2 \%)$, pendidikan terakhir responden paling banyak yaitu lulusan SMA/Sederajat sebanyak 26 orang $(39,4 \%)$ dan jenis kanker yang paling banyak diderita oleh responden yaitu ca mamae sebanyak 24 orang $(36,4 \%)$ serta hampir seluruh responden melakukan kemoterapi pada tahapan awal yaitu sebanyak 54 orang $(81,8 \%)$; Sebanyak 34 orang $(51,5 \%)$ menggunakan mekanisme koping maladaptif dan sisanya 32 orang (48,5\%) menggunakan mekanisme koping adaptif; Lebih dari separuh responden yaitu 41 orang $(62,1 \%)$ mengalami ansietas sedang, 14 orang $(21,2 \%)$ mengalami ansietas berat dan 11 orang $(16,7 \%)$ mengalami ansietas ringan; Ho gagal ditolak yang artinya data sampel tidak mendukung adanya perbedaan yang bermakna (signifikan) antara mekanisme koping dengan meningkatnya kejadian ansietas pada pasien dengan penyakit kanker di RSPAD Gatot Soebroto. Saran Bagi Pelayanan Dan Masyarakat, Hasil penelitian ini diharapkan dapat menjadi sumber bacaan yang bermanfaat serta menjadi masukan dalam meningkatkan mutu dan kualitas pelayanan terhadap tingkat kecemasan klien dengan penyakit kanker; Bagi Ilmu Keperawatan, Hasil penelitian ini diharapkan dapat menjadi bahan masukan dalam perkembangan ilmu kepeawatan mata ajar keperawatan jiwa khususnya penelitian yang berhubungan dengan kecemasan pada pasien penyakit kanker; Bagi Profesi Keperawatan, Hasil penelitian ini diharapkan menjadi masukan dalam pengembangan intervensi keperawatan khususnya promosi kesehatan tentang kanker dalam meningkatkan peran perawat sebagai pendidik dalam promosi kesehatan, pengelola serta pelaksana dalam upaya peningkatan pelayanan kesehatan di rumah sakit dan peneliti di bidang keperawatan; Bagi Institusi, Hasil penelitian ini diharapkan dapat digunakan sebagai bahan bacaan di perpustakaan dan dijadikan dokumentasi ilmiah untuk pengembangan kurikulum yang memerlukan masukan berupa data atau pengembangan penelitian di bidang keperawatan; Bagi Penulis, Hasil penelitian ini diharapkan dapat menambah pengetahuan, wawasan dan pengalaman peneliti di bidang perawatan klien dengan tingkat kecemasan yang menderita penyakit kanker serta mengembangkan ilmu yang diperoleh selama perkuliahan dan mengaplikasikan ilmu yang telah dipelajari; Bagi Peneliti Selanjutnya, Hasil penelitian ini diharapkan dapat menjadi acuan dalam penelitian mengenai mekanisme koping dan tingkat ansietas pada klien dengan penyakit kanker. Penelitian selanjutnya diharapkan dapat mengembangkan peneltian ini dengan menggunakan penelitian kuanlitatif sehingga hasil yang didapatkan akan lebih mendalam dan lebih mengembangkan hubungan antar variabel yang ada di karakteristik responden dengan variabel independen dan dependen. 


\section{REFERENSI}

1. Dharma, Kusuma Kelana. (2011). Metodologi Penelitian Keperawatan : Panduan Melaksanakan dan Menerapkan Hasil Penelitian. Jakarta: Trans Info Media.

2. Haris, Aila., dkk. (2015). Insiden dan Tingkat Anxiety-Depression pada Pasien Kanker Paru Menggunakan Hamilton Rating Scale.Diakses pada tanggal 4 Juni 2017. Dari http://jurnalrespirologi.org/wp-content/uploads/2015/08/JRI-Apr-2015-35-2-61-71.pdf

3. Keliat, B.A dan Akemat.(2012). Model Praktik Keperawatan Profesional Jiwa. Jakarta: EGC.

4. Kemenkes.(2007).http://www.aidsindonesia.or.id/uploads/20130506131833.Skmenkes_Nomor_812ME NKESSKVII2007_Tentang_Kebijakan_Perawatan_Paliatif.

5. Manurung, Nixson.(2016). Terapi Reminischence Solusi Pendekatan Sebagai Upaya Tindakan Keperawatan Dalam Menurunkan Kecemasan, Stress dan Depresi. Jakarta: Trans Info Media.

6. Notoadmodjo, S. (2010).Metodologi Penelitian Kesehatan. Jakarta: Rineka Cipta

7. Nurpeni, Dkk (2014). Hubungan Dukungan Keluarga Dengan Tingkat Kecemasan Pada Pasien Kanker Payudara (Ca Mammae) Di Ruang Angsoka Iii Rsup Sanglah Denpasar.Diakses pada tanggal 4 Juni 2017. Dari http://erepo.unud.ac.id/10051/

8. Nursalam.(2016). Konsep Dan Penerapan Metodologi Penelitian Ilmu Keperawatan Edisi 4. Jakarta: Salemba Medika

9. Rahmawati, Asri., Lestari, Arena., Setiawan, Ferry. (2015). Mekanisme Koping Berhubungan Dengan Tingkat Kecemasan Pasien Kemoterapi Di Ruang Kemoterapi Rs Urip Sumoharjo Lampung. Diakses tanggal 26 April 2017 dari http://ejournal.stikesmukla.ac.id/index.php/motor/article/view/222/218

10. Siswanto, Riyadi dan Purwanto T. (2007).Asuhan Keperawatan Jiwa. Yogyakarta: Graha Ilmu.

11. Sonia, Gina., Arifin, Helmi., Murni, Arina, Widjaya. (2014). Hubungan Mekanisme Koping Dengan Kepatuhan Kemoterapi Pada Penderita Keganasan Yang Mengalami Ansietas Dan Depresi. Dari https://www.google.co.id/search?q=Hubungan+Mekanisme+Koping+Dengan+Kepatuhan+Kemoterapi+ Pada+Penderita+Keganasan+Yang+Mengalami+Ansietas+Dan+Depresi\&oq=Hubungan+Mekanisme+ Koping+Dengan+Kepatuhan+Kemoterapi+Pada+Penderita+Keganasan+Yang+Mengalami+Ansietas+D an+Depresi\&aqs=chrome..69i57.968j0j9\&sourceid=chrome\&ie=UTF-8. Diakses tanggal 4 Juni 2017

12. Susilawati, Dwi. 2013. Hubungan Antara Dukungan Keluarga Dengan Tingkat Kecemasan Penderita Kanker Serviks Paliatif Di Rsup Dr Sardjito Yogyakarta. Diakses tanggal 1 April 2017.Dari http://ejournal.umm.ac.id/index.php/keperawatan/article/view/2358.

13. Stuart, G,W. (2013). Buku Saku Keperawatan Jiwa (pocket guide to psychiatric nursing). Edisi V. Jakarta: EGC

14. Syafaria, Triantoro \& Nofrans Saputra. (2009). Manajemen Emosi: Sebuah Panduan Cerdas Bagaimana Mengelola Emosi Positif dalam Hidup Anda. Jakarta: Bumi Aksara WHO, 2010.World Health Statistic. WHO Press: Geneva. http://www.who.int/ 